by Kazuhisa Goto $^{1}$, Shigehiro Fujino ${ }^{2}$, Daisuke Sugawara ${ }^{1}$ and Yuichi Nishimura ${ }^{3}$

\title{
The current situation of tsunami geology under new policies for disaster countermeasures in Japan
}

\author{
1 International Research Institute of Disaster Science, Tohoku University, 6-6-11 Aoba, Aramaki, Sendai, 980-8579, Japan. \\ (E-mail: goto@irides.tohoku.ac.jp) \\ 2 Faculty of Life and Environmental Sciences, University of Tsukuba, Tennodai, Tsukuba, Ibaraki 305-8572, Japan \\ 3 Institute of Seismology and Volcanology, Hokkaido University, Kita 10 Nishi 8, Kita-ku, Sapporo 060-0810, Japan
}

This paper presents a review of the Japanese policies for tsunami countermeasures before and after the 2011 off the Pacific coast of Tohoku Earthquake and its consequent tsunami. The current status of tsunami geology under the new policies is also discussed. The 2011 event was regarded as an unexpected hazard. Such a large hazard had not been considered for Japanese tsunami countermeasures before, although geological studies have indicated their potential occurrence. Based on lessons learned from the 2011 event, the Japanese government changed policies related to tsunami disaster countermeasures. The salient change is that estimation of the maximum possible earthquake and tsunami along the each coast of Japan is now required. Following this policy change, the maximum possible earthquake and tsunami have been estimated along several coasts of Japan, such as the Nankai Trough region based on seismology, irrespective of past occurrence. Tsunami geology is regarded as an important research field for estimating the maximum possible earthquake and tsunami strength because paleotsunami histories of several thousand years are crucially important for future tsunami risk assessment. However, many issues remain to be resolved to respond to the rapid change of policy. Acceleration of studies, sharing knowledge with governors, and development of schemes for outreach to the public (e.g. a database system) should be considered for improvement of future tsunami countermeasures in Japan.

\section{Introduction}

The 2011 off the Pacific coast of Tohoku Earthquake and its consequent tsunami that occurred on 11 March 2011 (Fig. 1a) marked an important turning point for earthquake and tsunami studies in Japan.
This was the first known earthquake with a magnitude greater than 9.0 and a recorded maximum tsunami run-up $(40.0 \mathrm{~m}$, Mori et al., 2012 ) in the past 1,300 years of Japanese historical records. The earthquake and tsunami caused 15,885 deaths, with 2,623 missing (as of 10 April 2014; Metropolitan Police Department, 2014), and severe accidents at the Fukushima Daiichi Nuclear Power Plant.

Although no clear differentiation of hazard and disaster exists in Japanese terminology, the Central Disaster Management Council (CDMC) (2011) defined the terms: "The 2011 off the Pacific coast of Tohoku Earthquake refers to the earthquake hazard of magnitude 9.0 that occurred on 11 March 2011 and was named by the Japan Meteorological Agency based on a standard naming convention. The Great East Japan Earthquake, named subsequently by the Cabinet, refers to the earthquake and tsunami disaster and the accompanying nuclear accidents". However, the "2011 Tohoku-Oki (or Tohokuoki) earthquake and tsunami" is more popularly used among scientists because important scientific journals such as Nature and Science have adopted the term for this event.

The sizes of both the 2011 earthquake and tsunami were far greater than previously estimated. Therefore, disaster prevention countermeasures against such hazards were insufficient. The event was designated as an unexpected ("souteigai" in Japanese) hazard (e.g., Goff et al., in press). However, even before the 2011 event, historical and geological results of studies had suggested the potential occurrence of a low-frequency large earthquake and tsunami along the Pacific coast of Tohoku (e.g., Abe et al., 1990; Minoura, 1990; Watanabe, 2001). In fact, the 869 Jogan earthquake and tsunami, which is now regarded as a possible predecessor of the 2011 event (e.g., Goto et al., 2011; Namegaya and Satake, 2014), has been well studied since the late 1980s. Based on geological studies of the Jogan tsunami, the minimum inundation area was $3-4 \mathrm{~km}$ inland from the paleo-shoreline (Sawai et al., 2007). An earthquake of $\mathrm{Mw}>8.3-8.4$ is necessary to explain the distribution of tsunami deposits (Satake et al., 2008a; Namegaya et al., 2010; Sugawara et al., 2011), and the magnitude is now revised as $\mathrm{Mw}>8.6$ based on the lessons learned from the 2011 event (Namegaya and Satake, 2014). The tsunami recurrence interval was estimated based on geological evidence accumulated over 3,000 years: approx. 800 years (Minoura and Nakaya, 1991), 600-1,300 years (Sawai et al., 2007), and now revised to be approx. 500-800 years (Sawai et al., 2012). Therefore, in a geological sense, the occurrence of such a large tsunami at the Pacific coast of Tohoku was almost on time. However, geological information 


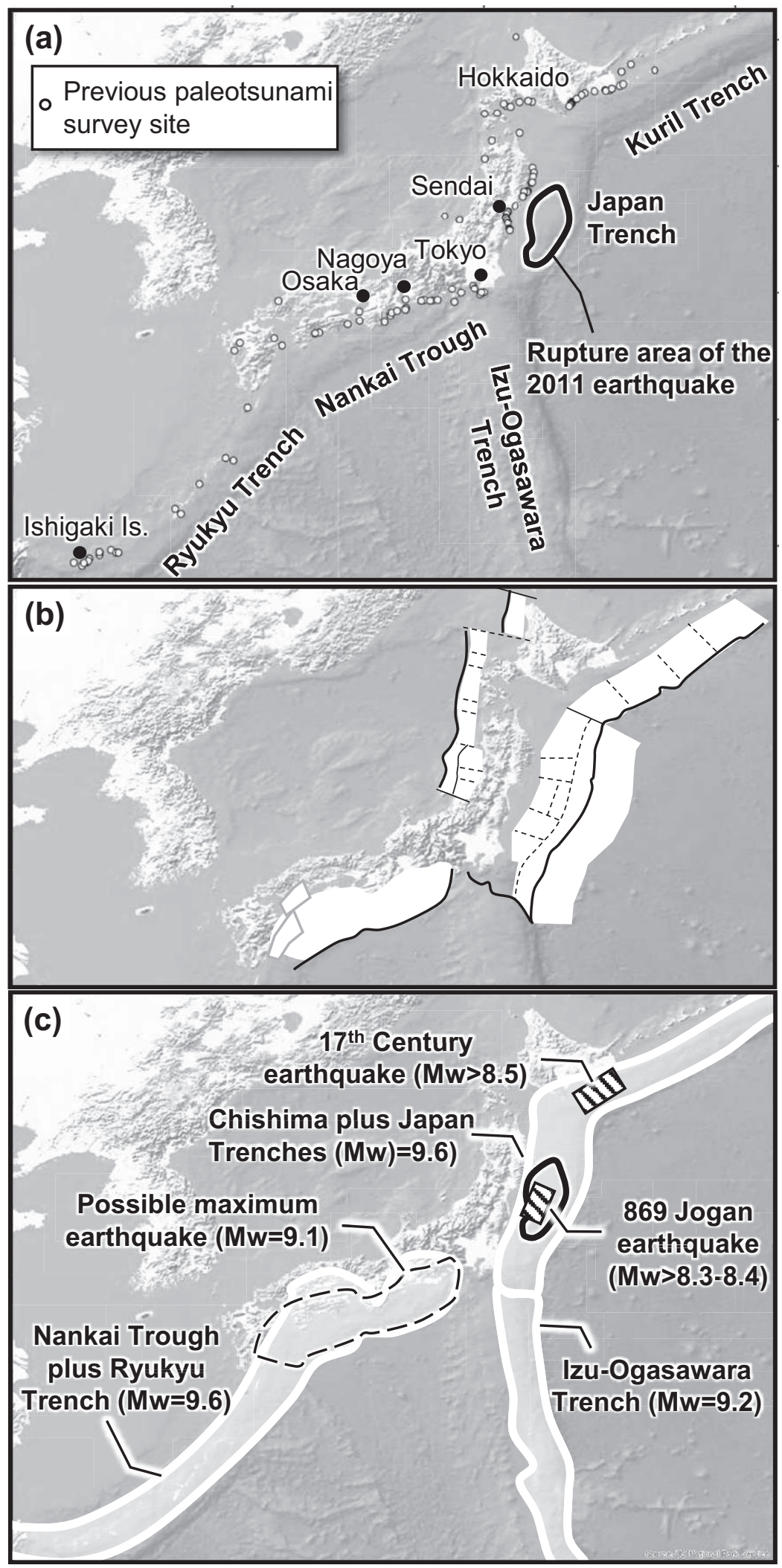

Figure 1. (a) Paleotsunami survey sites (after Goto et al., 2012) and rupture area of the 2011 earthquake (based on Ozawa et al., 2011). (b) Small segments defined by the Headquarters for Earthquake Research Promotion (based on the website of HERP: http://www.jishin.go.jp/main/p_hyoka02_kaiko.htm). (c) Location of paleotsunami source models (Satake et al., 2008b, 2010) as well as possible maximum fault models for the Nankai Trough by CDMC (2012) and other trenches by NRA (2013). had yet to be included in consideration of local tsunami countermeasures.

Based on lessons learned from the 2011 event, the Japanese government changed its policy for tsunami disaster countermeasures. The major change was that estimation of the maximum possible earthquake and tsunami along each coast of Japan is required, as described below. Paleotsunami histories of several thousand years are extremely valuable. Therefore, tsunami geology is now regarded as a major research field for estimating maximum possible earthquakes and tsunamis for each coast (e.g., CDMC, 2011). However, numerous issues remain, mostly because the geological research of tsunamis takes so much time that it cannot respond quickly to rapid changes in policy. Moreover, it is probably unclear to the governors and to the general public what tsunami geology can or cannot do for them. Therefore, some expectations extend beyond the current knowledge in this research field. Tsunami geologists should perform their duties with clear explanations of what they can accomplish using current knowledge and methods and what geologists should do to bridge the gap to new policy.

The Japanese policy change and recent government estimation of maximum strengths of possible earthquakes and tsunami events are followed closely by the general public in Japan. They receive considerable media attention, although little is reported outside Japan. However, it is probably beneficial for the research community and local governments throughout the world to know the current situation of tsunami countermeasures in Japan after the 2011 event, especially from a standpoint of tsunami geology, because it will be useful to consider future tsunami countermeasures in "at-risk areas" in the geological sense such as the area along the Cascadia subduction zone (e.g., Peterson et al., 2013). We, therefore, summarize the policies of tsunami countermeasures before and after the 2011 event in Japan, and discuss the current status of tsunami geology.

\section{General policies of the tsunami countermeasure before the 2011 event}

The CDMC under the Cabinet Office is the main organization responsible for disaster management policymaking in Japan. Separate from CDMC, individual earthquake and tsunami studies are reviewed by the committees under the Headquarters for Earthquake Research Promotion (HERP), which was founded after the Great Hanshin-Awaji Earthquake Disaster on January 17, 1995. The main objective of HERP is "to promote research into earthquakes with the goal of strengthening disaster prevention measures, particularly for the reduction of damage and casualties from earthquakes" (HERP, undated). In pursuit of this objective, they evaluate seismic activity of major subduction-zone earthquakes and inland active faults. They sectionalize 
the plate boundary into several smaller segments such as faults with $\mathrm{Mw}>7$ (Fig. 1b). Segments may slip simultaneously, generating larger earthquakes (e.g., Furumura et al., 2011; Seno, 2012): so-called multisegment earthquakes. Before 2011, this was the basic idea for evaluating the probability of future occurrences of large earthquakes along each trench.

For example, estimating the occurrence of large earthquakes along the Nankai Trough is extremely complex (Fig. 2, e.g., Furumura et al., 2011; Seno, 2012). The 1944 Showa Tonankai earthquake (Mw= 7.9) and the 1946 Showa Nankai earthquake $(\mathrm{Mw}=8.0)$ occurred individually over a two-year time interval (HERP, 2013). In 1854, the Ansei Nankai earthquake ( $\mathrm{Mw}=8.4$ ) occurred; 30 hours after the Ansei Tokai earthquake $(\mathrm{Mw}=8.4)$ occurred (HERP, 2013). In 1707, the Hoei earthquake $(\mathrm{Mw}=8.6-8.7)$ occurred and was interpreted as the largest multi-segment earthquake along the Nankai Trough. Before the 2011 event, the Hoei earthquake was regarded as the largest event along the Japanese archipelago in the past 1,300 years (HERP, 2013).
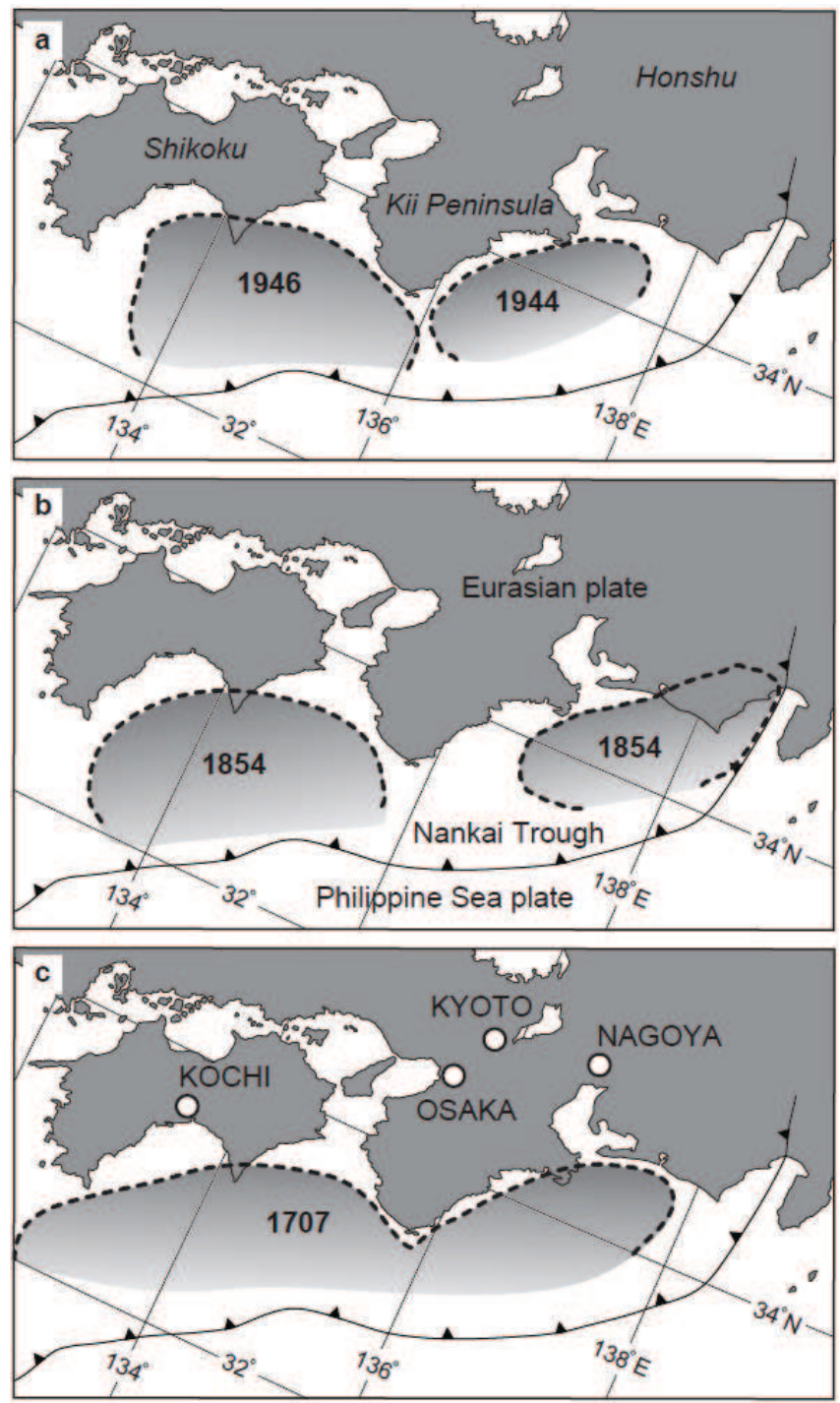

Figure 2. (a) Approximate rupture areas of the 1944 and 1946 earthquakes from Hatori (1974). (b) Approximate rupture areas of the two 1854 earthquakes from Hatori (1976). (c) Approximate rupture area of the 1707 earthquake from Hatori (1974). Western end of the rupture area extends westward for about $70 \mathrm{~km}$ based on Furumura et al. (2011).
It is noteworthy that all earthquakes described above were accompanied by large tsunamis (HERP, 2013). Tsunami-affected areas were broader in cases of multi-segment earthquakes, although the maximum run-up heights are almost constant at approx. $10 \mathrm{~m}$ (HERP, 2013), which indicates that the geological record of many previous events, whether for multi-segment earthquakes or not, might have been preserved in certain places such as coastal lowlands and lagoons. Nevertheless, it is difficult to ascertain from paleotsunami research whether the generating earthquake was a multi-segment type or not because no time resolution is available to differentiate earthquakes that occurred within several tens of years such as those of the 1944, 1946 or 1854 events.

Along the Japan Trench, large earthquakes, such as the "Miyagiken-oki earthquake", with a magnitude of 7.4 are known to occur on average every 37 years (Miyagi Prefecture, 2011). Since the last event in 1978, HERP predicted the probability of occurrence of a large earthquake as 70\% during the subsequent 10 years before 2011 (Miyagi Prefecture, 2011). It was also considered that a multi-segment earthquake with a magnitude of 8.0 might have occurred several times off Sendai Bay after the 17th century, based on the historical record. That probability was included in the consideration of tsunami countermeasures (Fig. 3, Miyagi Prefecture, 2004). However, a larger earthquake such as the 869 Jogan earthquake, with an estimated magnitude of $\mathrm{Mw}>8.3-8.4$ (Satake et al., 2008a; Namegaya et al., 2010; Sugawara et al., 2011), was not considered for disaster countermeasures before the 2011 event.

The Pacific coast of Hokkaido, which faces the Kuril Trench, is one of the rare places in Japan for which geological evidence was incorporated into tsunami countermeasures by the local government before 2011. This is true probably because Hokkaido has a short history in Japan. Fewer historical records pre-date the 17th century (e.g., Takashimizu, 2013), and therefore geological information is more important than for other areas of Japan. According to historical records gathered over the past 100 years, earthquakes with $\mathrm{Mw}=7$ to 8 are well known to occur repeatedly with an interval of a few tens of years in eastern Hokkaido (e.g., Takashimizu, 2013). However, geological records suggest the occurrence of larger events in the past. Nanayama and Shigeno (1998) and Hirakawa et al. (1998) reported tsunami deposits from the 17th century in eastern Hokkaido. Nanayama et al. (2003) further described the maximum inland extent of sand deposits as approx. $3 \mathrm{~km}$ and from these results, Nanayama et al. (2003) and Satake et al. (2008b) reported that a multi-segment earthquake with $\mathrm{Mw}>8.5$ must be assumed in order to explain the wide distribution of tsunami deposits in eastern Hokkaido. It is noteworthy that the tsunami recurrence interval in this region is well studied and is estimated to be about 500 years (Nanayama et al., 2003) or 300-500 years (Hirakawa et al., 2005), with aperiodic occurrences during a shorter period of 100-300 years plus a longer period of 600-700 years (Sawai et al., 2009).

The CDMC referred to the large earthquake hazard in eastern Hokkaido as a "500-year interval earthquake" (e.g., CDMC, 2006). This was probably the only case in which geological information had been effectively incorporated into policymaking for disaster prevention countermeasures before the 2011 event.

\section{Policy changes after the 2011 event}

After the 2011 event, historical and geological studies of the 869 Jogan event have been highlighted (e.g., Normile, 2011). The CDMC 



Figure 3. Estimated inundation areas of the 869 Jogan tsunami (after Sugawara et al., 2011) and 2011 tsunami (after Sugawara et al., 2013), and a tsunami hazard map issued before the 2011 event (Miyagi Prefecture, 2004).

established a committee for "Technical Investigation on Countermeasures for Earthquakes and Tsunamis Based on the Lessons Learned from the "2011 off the Pacific coast of Tohoku Earthquake" on 27 April 2011. The midterm report of the committee suggested that local governments consider two tsunami levels for future tsunami disaster prevention (Fig. 4):

Level 1 tsunami: One that occurs frequently every few tens of years to a hundred or more years. The estimated tsunami height is the basis for construction of shore protection facilities.

Level 2 tsunami: One that occurs with an extremely low frequency, but generating severe damage once it occurs. Shore protection facilities are probably insufficient to protect against a tsunami of this size. Saving human life is, therefore, the top priority, and hence so an awareness campaign including disaster education is highly recommended.

The final report of the committee was issued on 28 September 2011 (CDMC, 2011). The report concluded that “.... when conducting earthquake and tsunami hazard assumptions in the future, the largest-possible mega earthquakes and tsunamis should be considered from every possible angle". The report also noted that "....in order to verify the occurrence of mega tsunamis over a time scale of several thousand years it is vital that further enhancement be made not only to seismological research but also to the comprehensive geological, archaeological and historical research, including research into tsunami deposits on land and the ocean floor, geological research into coastal terraces, and research into biological fossils etc" (CDMC, 2011). This is a typical change after the 2011 event, inducing the Japanese government to consider every possibility to exclude future unexpected earthquakes and tsunami disasters.

On 27 December 2011, the Ministry of Land, Infrastructure, Transport and Tourism (MLIT) created a new law for urban development against tsunami disasters. Geological research for tsunami risk assessment is strongly recommended before preparing future local disaster prevention plans (MLIT, 2011). Subsequently, many prefectural or city governments, especially those along the coasts of at-risk areas, started to re-evaluate Level 1 tsunami events based mainly on numerical modeling for tsunami inundation by adopting source models that were tuned by historical and geological records as well as seismological data. However, the estimation of Level 2 tsunami events is not easy for local governments.

Following the policy changes described above, CDMC (2012) issued a report on 29 August 2012 concerning the maximum possible earthquake and tsunami strength along the Nankai Trough, where megacities such as Nagoya and Osaka are located. They assumed a magnitude 9.1 earthquake along the Nankai Trough (Fig. 1c) with a possible maximum tsunami run-up height of approx. $30 \mathrm{~m}$. The worst possible human and economic losses are estimated respectively as 320,000 people and 220 trillion yen (e.g., Asahi Newspaper, 2013). As acknowledged by the CDMC (2012), it is important to note that this fault model is not based on historical or geological evidence and that it far surpasses the largest known historical event (i.e., the 1707 Hoei event). The fault model parameters (e.g., slip amount or area) were actually estimated based on seismological lessons learned from

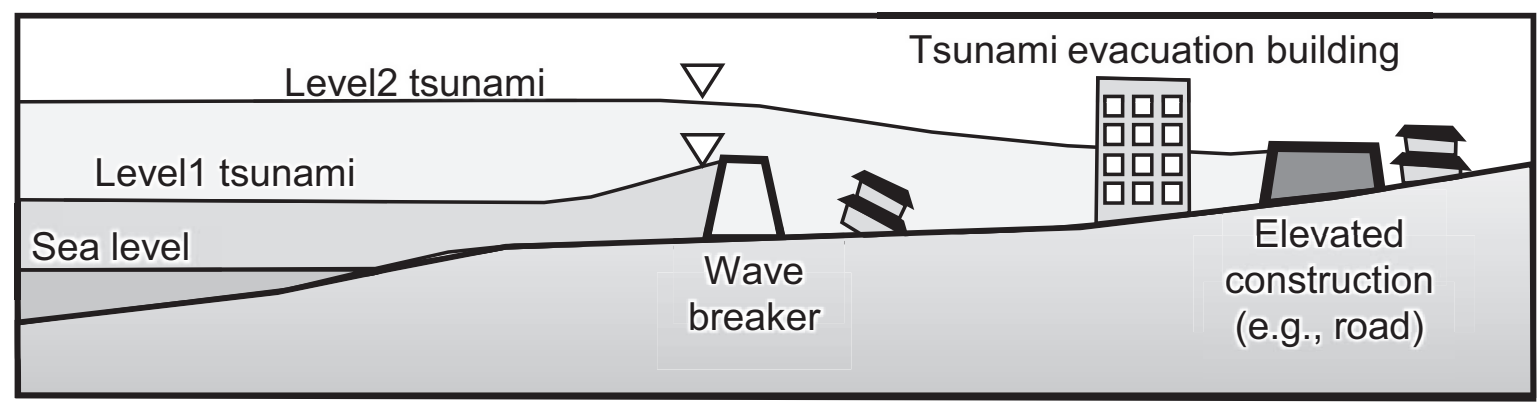

Figure 4. Illustration showing the difference of level 1 and 2 tsunamis and their countermeasures (based on Tokushima Prefecture, 2013). 
previous large earthquakes that occurred worldwide, such as the 2011 Tohoku-oki, 2010 Chilean earthquake, and 2004 Sumatra earthquake (CDMC, 2012). The report also noted the extreme difficulty of predicting the future occurrence of such an earthquake and tsunami. This is largely because no historical or geological evidence exists to support the occurrence of such an extreme event.

To the north, prior to 2011, a tsunami hazard map for Hokkaido was produced based on the known 17th century event (Hokkaido, 2007; Satake and Nanayama, 2005). However, following the 2011 event this was renewed and tsunami heights became several times larger than the previous estimation even though they used the same pre-2011 geological dataset (Hokkaido, 2012).

Based on lessons learned from the severe accident of Fukushima Daiichi Nuclear Power Plant, the Nuclear Regulation Authority (NRA) issued a screening guidebook for use in evaluating tsunami countermeasures for each nuclear power plant in Japan (NRA, 2013). The report described how to use a source model for a benchmark maximum possible earthquake and tsunami, the outputs of which were to be used to design prevention facilities for a nuclear power plant (NRA, 2013). The guidebook also noted the potential occurrence of tsunamis generated by non-seismic hazards (e.g., submarine landslides, caldera collapse) and that models of benchmark events for both seismic and non-seismic sources should produce larger waves than those estimated from existing historical and geological evidence.

As extreme examples, source models were produced for the following three regions (1) Kuril plus Japan Trenches (approximate maximum magnitude $(\mathrm{Mw})=9.6$ ), (2) Izu-Ogasawara Trench $(\mathrm{Mw}=9.2)$, and (3) Nankai Trough plus Ryukyu Trench $(\mathrm{Mw}=9.6)$, respectively (Fig. 1c), based on seismological knowledge obtained from past $\mathrm{Mw}>9$ earthquakes occurring throughout the world. This is far larger than the government-level estimation. Similarly to the CDMC (2012) assumption for the Nankai Trough, the NRA (2013) also acknowledged that no evidence currently exists to support the occurrence of such large earthquakes in the past. However, they reasoned that the evaluation of the tsunami hazard for nuclear power plants should be stricter, and safe-side countermeasures are strongly required for consideration of the possible occurrence of such extremely strong earthquakes.

\section{Perspective of tsunami geology}

As stated in the previous section, it seems reasonable that the Japanese government requests scientists to estimate the maximum possible tsunami along each coast. This is not necessarily based on previous events in each region, but considers lessons learned from other tsunamis around the world. More importantly, a quick response, from months to years, has been required to reflect scientific knowledge in the ongoing improvement of tsunami countermeasures. Indeed, the estimation of maximum possible earthquake and tsunami along Nankai Trough was done swiftly - within one and half years of the 2011 event.

Then, what can tsunami geology contribute to disaster countermeasures under these circumstances? Tsunami geology is undoubtedly useful in helping to better understand both historical and paleotsunamis. Paleotsunami studies are not only useful for paleoseismology, but they can also reveal the potential occurrence of non-seismic events. Therefore, tsunami research must continue in order to improve our understanding of both historical and prehistoric tsunamis, whether the tsunami origin was seismic or non-seismic.
However, for the very specific issue (exploring possible maximum earthquakes and tsunamis along the Japanese coast over a short time frame (e.g., 1-2 years)), we consider that the capabilities of tsunami geology are limited.

As the 869 Jogan tsunami studies showed, evidence-based studies usually take a lot of time to elucidate the nature of paleotsunamis. In fact, the 869 Jogan tsunami studies took more than 20 years to produce a scientific consensus. Although recent developments in tsunami geology may be sufficient to reduce the time taken for paleotsunami research, it is still probably difficult to contribute to the rapid revision of local governments' tsunami disaster mitigation plans within the next 1-2 years. Moreover, it is probably not straightforward to estimate the maximum possible earthquake and tsunami based solely on geological research because past events determined from paleotsunami research may not necessarily represent the maximum size of future events.

Estimating tsunami size from paleotsunami deposits also tends to underestimate the size of tsunamis and therefore underestimate earthquake magnitude (e.g., Goto et al., 2011; Namegaya and Satake, 2014). However, further improvement of methods are being made to estimate the sizes of paleotsunamis from geological evidence, based on field surveys (e.g. Goto et al., in press), various analyses (e.g., Goff et al., 2012; Chagué-Goff et al., 2012), and numerical modeling (e.g., Jaffe et al., 2012; Namegaya and Satake, 2014; Sugawara et al., 2014). These will better help to elucidate the nature and extent of paleotsunamis.

Equally, tsunami geology is also likely to be capable of evaluating the validity of presumed maximum tsunami inundation areas estimated though numerical modeling. For example, along the Nankai Trough, paleotsunami research at high elevations, where no historical evidence of tsunami inundation is available, but where possible inundation is suggested such as the model by CDMC (2012), would be important to test whether a maximum event that was estimated based on the seismology is an overestimation or an underestimation. However, at the moment, no results show quantitative support of the occurrence of an extremely large tsunami along the Nankai Trough estimated by CDMC (2012), although a potentially large event at around $2000 \mathrm{BP}$ has been implied (e.g., Okamura et al., 2012).

It is also extremely important to continue to pursue the study of paleotsunami evidence along the coasts based on the classical style of field surveys, even if these appear to take some considerable time. As Figure 1a shows, many places exist in which no paleotsunami research has been done. Indeed, very few studies have examined areas along the coast of the Sea of Japan, even though this is an area with numerous nuclear power plants. There is no geological data along the Izu-Ogasawara Trench and thus tsunami risk along this trench is poorly understood. Potential tsunami generation by non-seismic sources is also no small issue because such events are indeed "unexpected" in most cases. Tsunami geology might help to ascertain where and when such non-seismic tsunamis might occur (e.g., Maeno and Imamura, 2007).

Physical evidence such as tsunami deposits is also an important means of educating local people about large paleotsunamis that inundated their towns in the past. This is important for local people so that they can be better aware of the tsunami risk. For example, in 2013, tsunami boulders on Ishigaki Island (Fig. 5), some of which were deposited by the 1771 Meiwa tsunami (e.g., Goto et al., 2010; Araoka et al., 2013), were designated as national monuments, which is probably the first example of geological evidence of a paleotsunami 


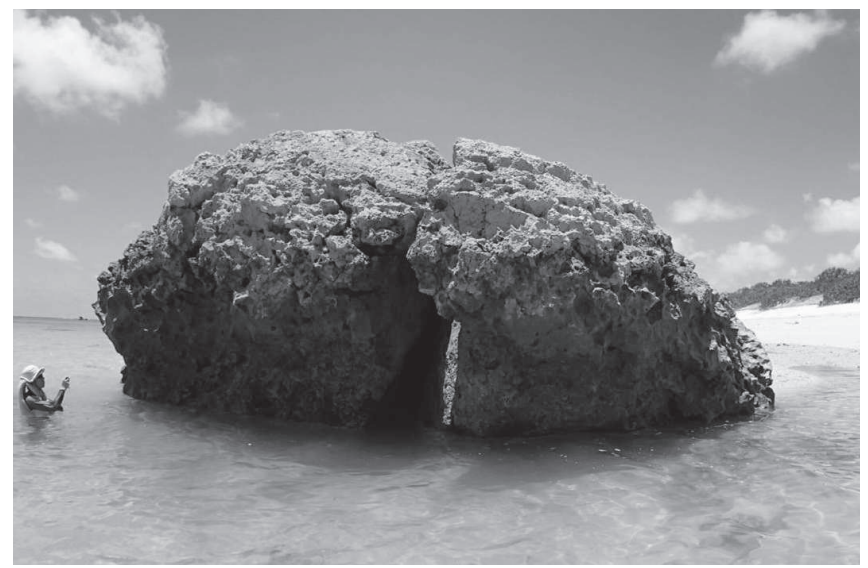

Figure 5. Largest Porites coral boulder in eastern Ishigaki Island, Japan, which was deposited by the 1771 Meiwa tsunami based on the sedimentological observation (e.g., Goto et al., 2010) and radiocarbon dating (Araoka et al., 2013). This was designated as a national monument in Japan in 2013.

being so designated in Japan. Such evidence is important for disaster education purposes because people can be made aware of how large a tsunami was that struck an area in the past.

Another important issue is how to provide scientific results to the public. Satake and Nanayama (2005) provided maps of historical and prehistoric tsunami inundation zones for eastern Hokkaido that included the 17th century event. Alternatively, the "Japan Tsunami Trace Database" developed by Tohoku University and Japan Nuclear Energy Safety (JNES, currently NRA) is available on the web (http:/ /tsunami-db.irides.tohoku.ac.jp/) and approx. 30,000 data points of tsunami heights based on historical records are included with validation. Database systems for tsunami deposits have been developed in the USA (Peters and Jaffe, 2010), New Zealand (Goff et al., 2010) and Australia (Goff and Chagué-Goff, 2014), but no Japanese version has yet been developed. With JNES support, we preliminary constructed a web database system for tsunami deposits, which is compatible with the Japan Tsunami Trace Database. Such a database might help local governors and the general public to better understand their local tsunami histories based on these historical and geological records.

Because of the circumstances described above, tsunami geology in Japan has become a richly interdisciplinary research field. In fact, not only geologists but researchers in other fields, along with engineers, governors, and private companies have been conducting investigations. This represents important progress in accelerating studies of how to differentiate tsunami deposits from other extreme events, how to use geological evidence for risk assessment, and how to communicate with local people because answers to these questions must be explored from various angles. Future communication between interdisciplinary researchers and governors must be carried out in order to improve the transfer of knowledge about tsunami geology efficiently and to consider how to use this scientific evidence to improve countermeasures.

\section{Acknowledgements}

Part of this study was supported by the Japan Nuclear Energy Safety (currently Nuclear Regulation Authority) and by Grants-in-
Aid for Scientific Research from the Japan Society for the Promotion of Science (K. Goto, 26302007). We thank J. Goff for his valuable suggestions and comments on the manuscript.

\section{References}

Abe, H., Sugeno, Y., and Chigama, A., 1990, Estimation of the Height of the Sanriku Jogan 11 Earthquake-Tsunami (A.D. 869) in the Sendai Plain: Zishin (Journal of the Seismological Society of Japan), Second Series, v. 43 (4), pp. 513-525. (in Japanese with English abstract)

Araoka, D., Yokoyama, Y., Suzuki, A., Goto, K., Miyagi, K., Miyazawa, K., Matsuzaki, H., and Kawahata, H., 2013, Tsunami recurrence revealed by Porites coral boulders in the southern Ryukyu Islands, Japan: Geology, v. 41, pp. 919-922.

Central Disaster Management Council, 2011, Report of the Committee for Technical Investigation on Countermeasures for Earthquakes and Tsunamis Based on the Lessons Learned from the "2011 off the Pacific coast of Tohoku Earthquake". 50p. http://www.bousai.go.jp/kaigirep/ chousakai/tohokukyokun/pdf/Report.pdf

Central Disaster Management Council, 2006, Report of damage estimation by the subduction zone earthquake along Japan and Kuril Trenches. 79p (in Japanese). http://www.bousai.go.jp/kaigirep/chuobou/senmon/ nihonkaiko_chisimajishin/pdf/houkokusiryou1.pdf

Central Disaster Management Council, 2012, Report of investigative commission of large earthquake at Nankai Trough (second report) tsunami fault model. 103p. (in Japanese). http://www.bousai.go.jp/jishin/ nankai/nankaitrough_info.html

Chagué-Goff, C., Andrew, A., Szczucinski, W., Goff, J., and Nishimura, Y., 2012, Geochemical signatures up to the maximum inundation of the 2011 Tohoku-oki tsunami - implications for the 869 AD Jogan and other palaeotsunamis: Sedimentary Geology, v. 282, pp. 65-77.

Furumura, T., Imai, K., and Maeda, T., 2011, A revised tsunami source model for the 1707 Hoei earthquake and simulation of tsunami inundation of Ryujin Lake, Kyushu, Japan: Journal of Geophysical Research, v. 116, B02308.

Goff, J., and Chagué-Goff, C., 2014, The Australian tsunami database - A review: Progress in Physical Geography, v. 38, pp. 218-240.

Goff, J., Nichol, S., Kennedy, D., 2010, Development of a palaeotsunami database for New Zealand: Natural Hazards, v. 54, pp. 193-208.

Goff, J., Chagué-Goff, C., Dominey-Howes, D., Nichol, S., and Jaffe, B., 2012, Progress in palaeotsunami research: Sedimentary Geology, v. 243244, pp. 70-88.

Goff, J., Terry, J. P., Chague-Goff, C., and Goto, K., What is a mega-tsunami?: Marine Geology, in press. 10.1016/j.margeo.2014.03.013

Goto, K., Miyagi, K., Kawamata, H., and Imamura, F., 2010, Discrimination of boulders deposited by tsunamis and storm waves at Ishigaki Island, Japan: Marine Geology, v. 269, pp. 34-45.

Goto, K., Chagué-Goff, C., Fujino, S., Goff, J., Jaffe, B., Nishimura, Y., Richmond, B., Sugawara, D., Szczucinski, W., Tappin, D.R., Witter, R., and Yulianto, E., 2011, New insights of tsunami hazard from the 2011 Tohoku-oki event: Marine Geology, v. 290, pp. 46-50.

Goto, K., Nishimura, Y., Sugawara, D., and Fujino, S., 2012, The Japanese tsunami deposit studies: Journal of Geological Society of Japan, v. 118, pp. 431-436. (in Japanese with English abstract)

Goto, K., Hashimoto, K., Sugawaran D., Yanagisawa, H., and Abe, T., Spatial thickness variability of the 2011 Tohoku-oki tsunami deposits along the coastline of Sendai Bay: Marine Geology, in press. doi:10.1016/ j.margeo.2013.12.015

Hatori, T., 1974, Sources of large tsunamis in southwest Japan: Zishin (Journal of the Seismological Society of Japan), Second Series, v. 27, pp. 10-24. (in Japanese with English abstract)

Hatori, T., 1976, Documents of tsunami and crustal deformation in Tokai District associated with the Ansei Earthquake of Dec. 23, 1854: Bulletin of the Earthquake Research Institute, v. 51, pp. 13-28. (in Japanese with English abstract) 
Headquarters for Earthquake Research Promotion, 2013, Long-term evaluation of seismic activities along the Nankai Trough (second edition): 96p. (in Japanese). http://www.jishin.go.jp/main/chousa/kaikou_pdf/ nankai_2.pdf

Hirakawa, K., Nakamura, Y., and Echigo, T., 1998, Tsunami deposits on the terrace surface at Tokachi coast of Hokkaido: Programs and abstract of Seismological Society of Japan, C56. (in Japanese)

Hirakawa, K., Nakamura, Y., and Nishimura, Y., 2005, Holocene large tsunamis at the Pacific coast of Hokkaido: Comparison with the 2003 Tokachi-oki earthquake and tsunami: Chikyu Monthly, v. 49, pp. 173180. (in Japanese)

Hokkaido, 2007, Tsunami inundation map at the Pacific coast of Hokkaido. (in Japanese). http://www.bousai-hokkaido.jp/BousaiPublic/html/ common/sim_tsunami/rep/00_report_zendou.html

Hokkaido, 2012, Tsunami inundation map at the Pacific coast of Hokkaido. (in Japanese). http://www.pref.hokkaido.1g.jp/sm/ktk/bsb/tunami/ index.htm

Jaffe, B., Goto, K., Fujino, S., Sugawara, D., Nishimura, Y., and Richmond, B., 2012, Flow speed estimated by inverse modeling of sandy tsunami deposits: results from the 11 March 2011 tsunami on the coastal plain near the Sendai Airport, Honshu, Japan: Sedimentary Geology, v. 282, pp. 90-109.

Maeno, F. and Imamura, F., 2007, Numerical investigations of tsunamis generated by pyroclastic flows from the Kikai caldera, Japan: Geophysical Research Letters, v. 34, L23303.

Ministry of Land, Infrastructure, Transport and Tourism, 2011, Basic guideline for implementation of regional construction with tsunami disaster prevention. (in Japanese). http://www.mlit.go.jp/common/000188287. pdf.

Miyagi Prefecture, 2004, Master plan of the beach protection along the coast of Sendai Bay: 66 pp•D(in Japanese) http://www.pref.miyagi.jp/soshiki/ kasen/ka-sendaiwan.html

Mori, N., Takahashi, T., and the 2011 Tohoku earthquake tsunami joint survey group, 2012, Nationwide post event survey and analysis of the 2011 Tohoku Earthquake Tsunami: Coastal Engineering Journal, v. 54, 27 p., doi: 10.1142/S0578563412500015.

Minoura, K., 1990, Emergence and period of large-scale tsunamis in northeast Japan: Rekishi-Zishin, v. 6, pp. 61-76. (in Japanese)

Minoura, K., and Nakaya, S., 1991, Traces of tsunami preserved in intertidal lacustrine and marsh deposits: some examples from northeast Japan: Journal of Geology, v. 99, pp. 265-287.

Miyagi Prefecture, 2004, Report of damage estimation in Miyagi Prefecture. (in Japanese). http://www.pref.miyagi.jp/soshiki/kikitaisaku/kssanzihigai-houkoku.html

Miyagi Prefecture, 2011, Recurrence interval of the Miyagiken-oki earthquake. (in Japanese). http://www.city.sendai.jp/kurashi/shobo/ shiryo/0053.html

Namegaya, Y., and Satake, K., Reexamination of the AD 869 Jogan earthquake size from tsunami deposit distribution, simulated flow depth, and velocity: Geophysical Research Letters, v. 41, pp. 2297-2303. doi: 10.1002/ 2013GL058678

Namegaya, Y., Satake, K., and Yamamoto, S., 2010, Numerical simulation of the AD 869 Jogan tsunami in Ishinomaki and Sendai plains and Ukedo river-mouth lowland: Annual Report of Active Fault and Paleoearthquake Researches, v. 10, pp. 1-21. (in Japanese, with English abstract)

Nanayama, F., and Shigeno K., 1998, Historical tsunami deposits along the Kuril Trench at eastern Hokkaido: Kaiyo Monthly, v. 15, pp. 177-182. (in Japanese)

Nanayama, F., Satake, K., Furukawa, R., Shimokawa, K., Atwater, B.F., Shigeno, K., and Yamaki, S., 2003, Unusually large earthquakes inferred from tsunami deposits along the Kuril trench: Nature, v. 424, pp. 660663.

Normile, D., 2011, Scientific consensus on Great Quake came too late: Science, v. 332, pp. 22-23.
Nuclear Regulation Authority, 2013, Review guide for design-basis tsunami and design policy against tsunami. 42p. (in Japanese)

Okamura, M., and Matsuoka, H., 2012, Recurrence of Nankai earthquake based on the tsunami deposit. Kagaku, v. 82, 182-191. (in Japanese)

Ozawa, S., Nishimura, T., Suito, H., Kobayashi, T., Tobita, M., and Imakiire, T., 2011, Coseismic and postseismic slip of the 2011 magnitude-9 TohokuOki earthquake: Nature, v. 475, pp. 373-376.

Peterson, C.D., Clague, J.J., Carver, G.A., and Cruikshank, K.M., 2013, Recurrence intervals of major paleotsunamis as calibrated by historic tsunami deposits in three localities: Port Alberni, Cannon Beach, and Crescent City, along the Cascadia margin, Canada and USA: Natural Hazards, v. 68, pp. 321-336.

Peters, R., and Jaffe, B.E., 2010, Database of recent tsunami deposits: US Geological Survey Open-File Report 2010-1172 (12 pp.)

Satake, K., and Nanayama, F., 2005, Records of tsunami reach on the Hokkaido pacific coast: Geological Survey of Japan, National Institute of Advanced Industrial Science and Technology, CD-ROM. (in Japanese).

Satake, K., Namegaya, Y., and Yamaki, S., 2008a, Numerical simulation of the AD 869 Jogan tsunami in Ishinomaki and Sendai plains: Annual Report of Active Fault and Palaeoearthquake Researches, v. 8, pp. 7189 (in Japanese with English abstract).

Satake, K., Nanayama, F., and Yamaki, S., 2008b, Fault models of unusual tsunami in the $17^{\text {th }}$ century along the Kuril Trench: Earth Planets Space, v. 60, pp. 925-935.

Sawai, Y., Shishikura, M., Okamura, Y., Takada, K., Matsu'ura, T., Aung, T.T., Komatsubara, J., Fujii, Y., Fujiwara, O., Satake, K., Kamataki, T., and Sato, N., 2007, A study of paleotsunami using handy geoslicer in Sendai Plain (Sendai, Natori, Iwanuma, Watari, and Yamamoto), Miyagi, Japan: Annual Report on Active Fault and Paleoearthquake Researches, v. 7, pp. 47-80. (in Japanese with English abstract).

Sawai, Y., Kamataki, T., Shishikura, M., Nasu, H., Okamura, Y., Satake, K., Thomson, K.H., Matsumoto, D., Fujii, Y., Komatsubara, J., and Aung, T.T., 2009, Aperiodic recurrence of geologically recorded tsunamis during the past 5500 years in eastern Hokkaido, Japan: Journal of Geophysical Research, v. 114, B013191.

Sawai, Y., Namegaya, Y., Okamura, Y., Satake, K., and Shishikura, M., 2012, Challenges of anticipating the 2011 Tohoku earthquake and tsunami using coastal geology: Geophysical Research Letters, v. 39, L21309.

Seno, T., 2012, Great earthquakes along the Nankai Trough -A new idea for their rupture mode and time series: Zishin (Journal of Seismological Society of Japan), Second Series, v. 64, pp. 97-116. (in Japanese with English abstract)

Sugawara, D., Imamura, F., Matsumoto, H., Goto, K., and Minoura, K., 2011, Reconstruction of the AD869 Jogan earthquake induced tsunami by using the geological data: Journal of Natural Disaster Science, v. 29 (4), pp. 501-516. (in Japanese with English abstract)

Sugawara, D., Imamura, F., Goto, K., Matsumoto, H., and Minoura, K., 2013, The 2011 Tohoku-oki Earthquake Tsunami: Similarities and Differences between the 869 Jogan Tsunami on the Sendai Plain: Pure and Applied Geophysics, v. 70(5), pp. 831-845

Sugawara, D., Goto, K., and Jaffe, B., 2014, Numerical models of tsunami sediment transport -Current understanding and future directions: Marine Geology, v. 352, pp. 295-320.

Takashimizu, Y., 2013, Review of previous studies on tsunami deposits in Hokkaido, northern Japan: Focusing on the studies of deposits from $17^{\text {th }}$ Century large tsunamis and others: Journal of Geological Society of Japan, v. 119, pp. 599-612. (in Japanese with English abstract)

Tokushima Prefecture, 2013, Sea level of the designed tsunami. (in Japanese) http://www.pref.tokushima.jp/docs/2013032900154/

Watanabe, H., 2001. Is it possible to clarify the real state of past earthquakes and tsunamis on the basis of legends? As an example of the 869 Jogan earthquake and tsunami: Rekishi-Zishin, v. 17, pp. 130-146. (in Japanese)

NOTE: English titles of Japanese papers were translated by authors. 